\title{
Application of Grass Cover Failure Models Following in Situ Wave Overtopping Experiments in Belgium
}

\author{
Patrik Peeters ${ }^{1, *}$, Leen De $\operatorname{Vos}^{2}$, Bart Vandevoorde ${ }^{3}$, Jentsje van der Meer ${ }^{4}$ \\ ${ }^{1}$ Flanders Hydraulics Research, Antwerpen, Belgium \\ ${ }^{2}$ Flanders Geotechnical Division, Gent, Belgium \\ ${ }^{3}$ Research Institute for Nature and Forest, Brussels, Belgium \\ ${ }^{4}$ Van der Meer Consulting, Heerenveen, The Netherlands \\ *Corresponding Author: P.Peeters@tudelft.nl
}

Copyright (C) 2013 Horizon Research Publishing All rights reserved.

\begin{abstract}
In situ wave overtopping tests were performed on typical dike structures along the Schelde in Flanders (Belgium) with the Dutch Wave Overtopping Simulator. For a storm duration of 2 hours, wave overtopping characteristics were derived for significant wave heights ranging from 0,75 to $1 \mathrm{~m}$ and peak periods between 3 and $4 \mathrm{~s}$. Prior to the in situ experiments, soil investigations were executed together with a detailed study of the quality of the grass cover. During the tests, video recordings were made and detailed pictures of the damage were taken. Water content and evolution of the grass cover were monitored. At one location, no failure was experienced up to $50 \mathrm{l} / \mathrm{s}$ per m, even after applying initial damage to the surface protection. Other locations failed after facing $30 \mathrm{l} / \mathrm{s}$ per $\mathrm{m}$. Besides the cumulative overload method, available failure models are derived for steady overtopping conditions. Assuming erosion equivalence with unsteady overtopping conditions, different erosion resistance as well as (superficial) slip models are applied. Outcomes of the models are compared to the results of the in situ wave overtopping tests in Flanders (Belgium). Different approaches for describing the load term are discussed. Whether for unsteady overtopping conditions, erosion is predominant determined by the front velocity or an approximation of the average velocity of consecutive waves still needs further investigation. However, this discussion is maybe rather philosophical, because one's choice has a direct influence on the threshold values under which waves are not accounted for. For all methods, the determination of threshold values given different qualities of covering is at-the-time still questionable.
\end{abstract}

Keywords Wave Overtopping Simulator, Erosion, Grass Cover Failure

\section{Introduction}

In Flanders (Belgium) safety and ecological needs along the river Schelde need to be satisfied in a sustainable way. To reach this aim, the Sigmaplan, originally developed in 1977, was actualized in 2005. In this Actualized Sigmaplan [1], different restoration techniques, which combine safety with estuarine restoration, are explained in detail, e.g. the combination of dike strengthening measures with efforts to allow more room for the river. The latter can be obtained by creating flood control areas with or without a controlled reduced tide, non-tidal wetlands, ...

When constructing dikes, the Sigmaplan foresees in an arbitrary chosen freeboard of $0,5 \mathrm{~m}$ to limit possible wave overtopping, as this can lead to erosion and hence cause failure of the grass cover, which can in turn can be the first step towards a breach of the embankment.

Grass cover failure, however, According to Valk [2] different types of erosion can be distinguished (Fig. 1). Failure (due to erosion) of the grass cover is commonly predicted from hydraulic indicators like flow velocity $\mathrm{u}$, shear stress $\tau\left(u^{2}\right)$ and stream power or work $W\left(u^{3}\right)[3,4]$. The CIRIA publication by Hewlett [5] contains the widely used velocity-duration curves for acceptable erosion of various coverings due to steady overtopping. In Temple [6] the time of vegetal cover failure under continuous flow conditions is described as a function of the plasticity index (Ip) of the topsoil and the (effective) shear stress. Young [7] describes turf sliding (superficial slip erosion) of the grass cover as one of the possible failure mechanisms when subjected to (un)steady overtopping. Despite the extensive use of these formulae for steady overflow conditions, validation for unsteady overtopping is lacking. 


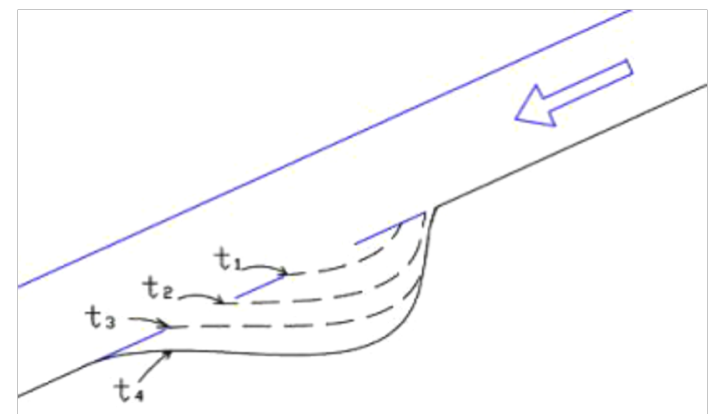

Surface erosion

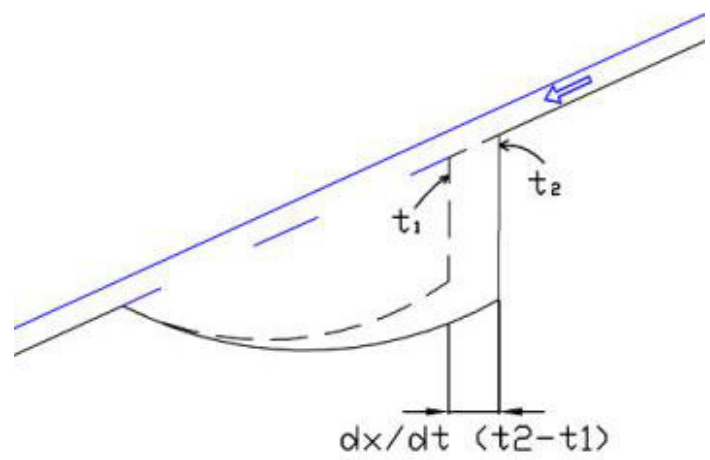

Headcut erosion

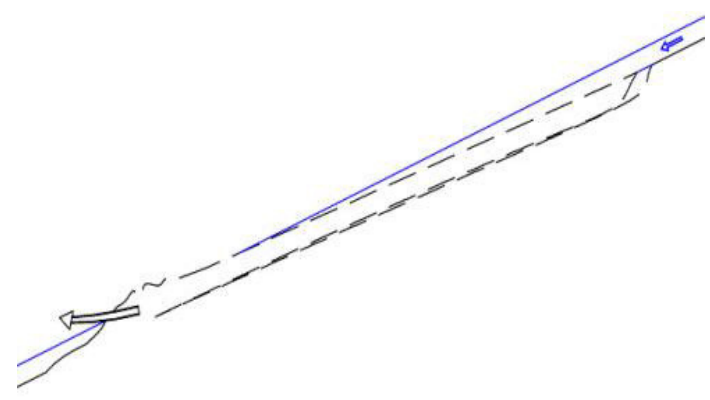

Superficial slip erosion (turf sliding)

Figure 1. Different types of erosion of the grass cover.

In order to obtain insight into the driving forces, factors and mechanisms involved in grass cover failure following unsteady overtopping, full scale tests were performed on typical dike structures along the Schelde with the Dutch Wave Overtopping Simulator. During these tests, the focus was on (estuarine) river conditions, however, at one test section coastal wave conditions were simulated.

The outcomes of the in situ overtopping tests in Flanders (Belgium). will be used to validate four failure (prediction) models. The grass-cover curves from [5] are applied assuming an erosion equivalence with continuous overflow and accounting only for those waves exceeding a threshold value which is function of the quality of the grass cover, as proposed by Dean [4]. In the same way, a model for the time of vegetal cover failure [6] and a superficial slip model [7] are applied to wave overtopping conditions assuming an erosion equivalence. Finally, the cumulative overload method [8] in which not the duration but only the front velocity of waves exceeding a threshold (again function of the quality of the grass cover) are accounted for, is verified.

\section{Test Setup, Conditions and Outcomes}

Figure 2 shows the principle of the wave overtopping simulator [9]. Wave overtopping was simulated at four test sections. Section 1, 2 and 4 (Fig. 3) were located very close to each other on the same dike and are more or less identical with a slope of 1:2.5, presence of concave irregularities (less pronounced in section 4), a rugged vegetation and some initial bare spots. Section 2 showed some more nettles and thistles. Section 3 (Fig. 4) is located on a different dike with a milder slope (1:3.5) and a rather uniform vegetation. The slopes of sections 1, 2 and 4 consist of silty sand to sandy silt, with an Ip varying between 5 and 10 . The slopes of section 3 consist of silty to clayey sand with a plasticity number varying between 10 to 30 . Average overtopping discharges ranging from 1 to $50 \mathrm{l} / \mathrm{s}$ per $\mathrm{m}$ with individual overtopping volumes up to $4,500 \mathrm{l} / \mathrm{m}$ were applied $[10,11]$. Table 1 gives an overview of relevant overtopping parameters.

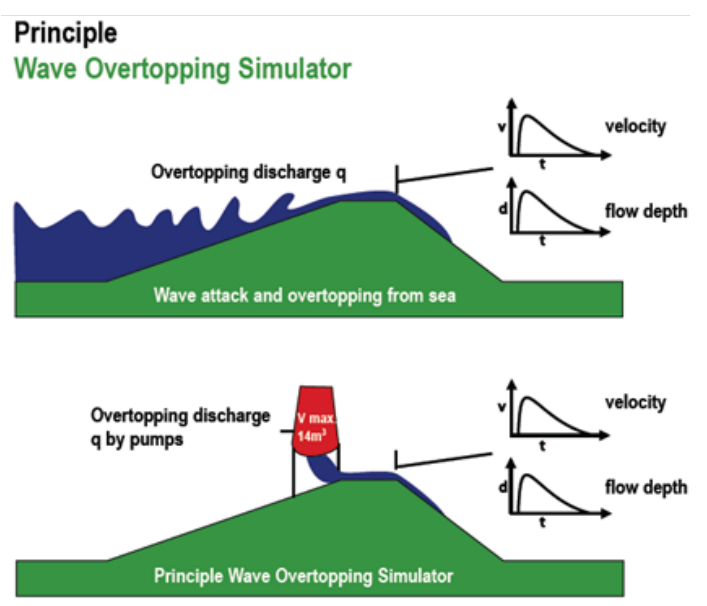

Figure 2. Principle of wave overtopping simulator.

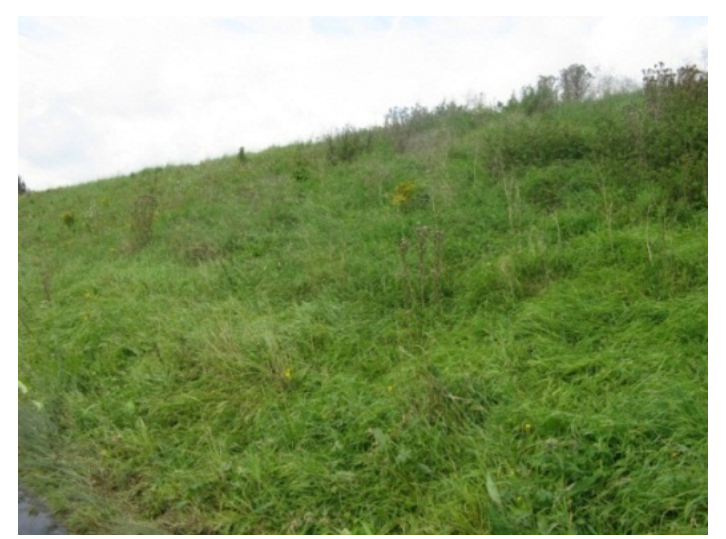

Figure 3. Overview of the test locations 1-2-4 


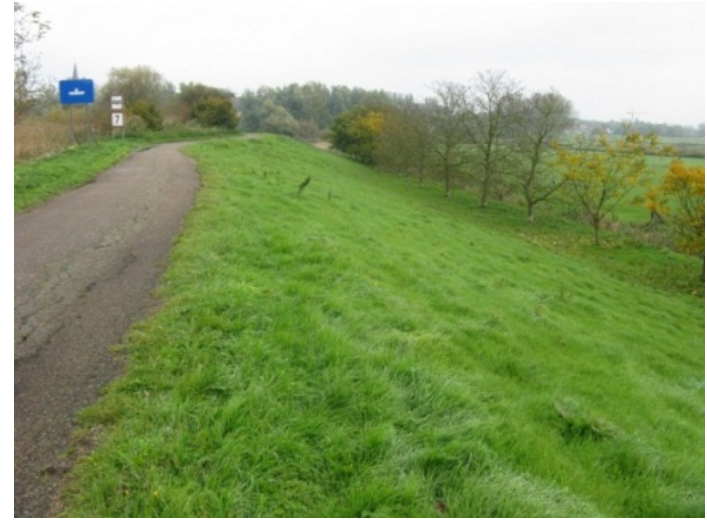

Figure 4. Overview of the test location and 3 progressive manner starting with $1 \mathrm{l} / \mathrm{s}$ per $\mathrm{m}$ until failure (severe damage of the grass cover) is noticed (Fig. 5). At sections 1 and 2 failure occurred at almost the same time, resp. after 20 and 35 minutes of simulating $30 \mathrm{l} / \mathrm{s}$ per $\mathrm{m}$ (following 1 and $10 \mathrm{l} / \mathrm{s}$ per $\mathrm{m}$ wave overtopping conditions). Section 3 did not show any damage after 2 hours of simulating $50 \mathrm{l} / \mathrm{s}$ per $\mathrm{m}$ (following 1, 10 and $30 \mathrm{l} / \mathrm{s}$ per $\mathrm{m}$ ). Finally section 4 failed after 3 hours of simulating $10 \mathrm{l} / \mathrm{s}$ per $\mathrm{m}$ (following 1 and $5 \mathrm{l} / \mathrm{s}$ per $\mathrm{m}$ ). Although the predominant erosion mechanism seemed to be surface erosion, superficial (translational) slip in between two waves was noticed. In addition, the presence of small steps or headcuts possibly allow erosion caused by an impinging jet. No upstream headcut migration took place.

The wave overtopping experiments were executed in a

Table 1. Overtopping parameters.

\begin{tabular}{|c|c|c|c|c|c|c|c|}
\hline & \multicolumn{3}{|c|}{$\begin{array}{c}\text { Estuarine wave conditions } \\
\text { (sections 1 to 3) }\end{array}$} & \multicolumn{3}{c|}{$\begin{array}{c}\text { Coastal wave conditions } \\
\text { (section 4) }\end{array}$} \\
\hline Average overtopping discharge q (1/s per m) & 1 & 10 & 30 & 50 & \multirow{2}{*}{1} & 5 & 10 \\
\hline Significant wave height $\mathrm{H}_{\mathrm{s}}(\mathrm{m})$ & 0.75 & 0.75 & 1 & 1 & 3 & 3 & 3 \\
\hline Peak wave period $\mathrm{T}_{\mathrm{p}}(\mathrm{s})$ & 3.1 & 3.1 & 3.6 & 3.6 & 6.2 & 6.2 & 6.2 \\
\hline Percentage of overtopping waves $\mathrm{P}_{\mathrm{ov}}$ & 10.2 & 43.5 & 58.0 & 69.3 & 1.4 & 6.8 & 12.0 \\
\hline Number of overtopping waves $\mathrm{N}_{\mathrm{ov}}$ & 295 & 1264 & 1450 & 1733 & 20 & 98 & 259 \\
\hline Max. overtopping volumes $(1 / \mathrm{m})$ & 209 & 659 & 1766 & 2544 & 2254 & 3478 & 4509 \\
\hline Test duration $(\mathrm{min})$ & $120^{*}$ & 120 & 120 & 120 & $120^{*}$ & 120 & $120+60$ \\
\hline
\end{tabular}

*Simulated 2 to 5 times faster
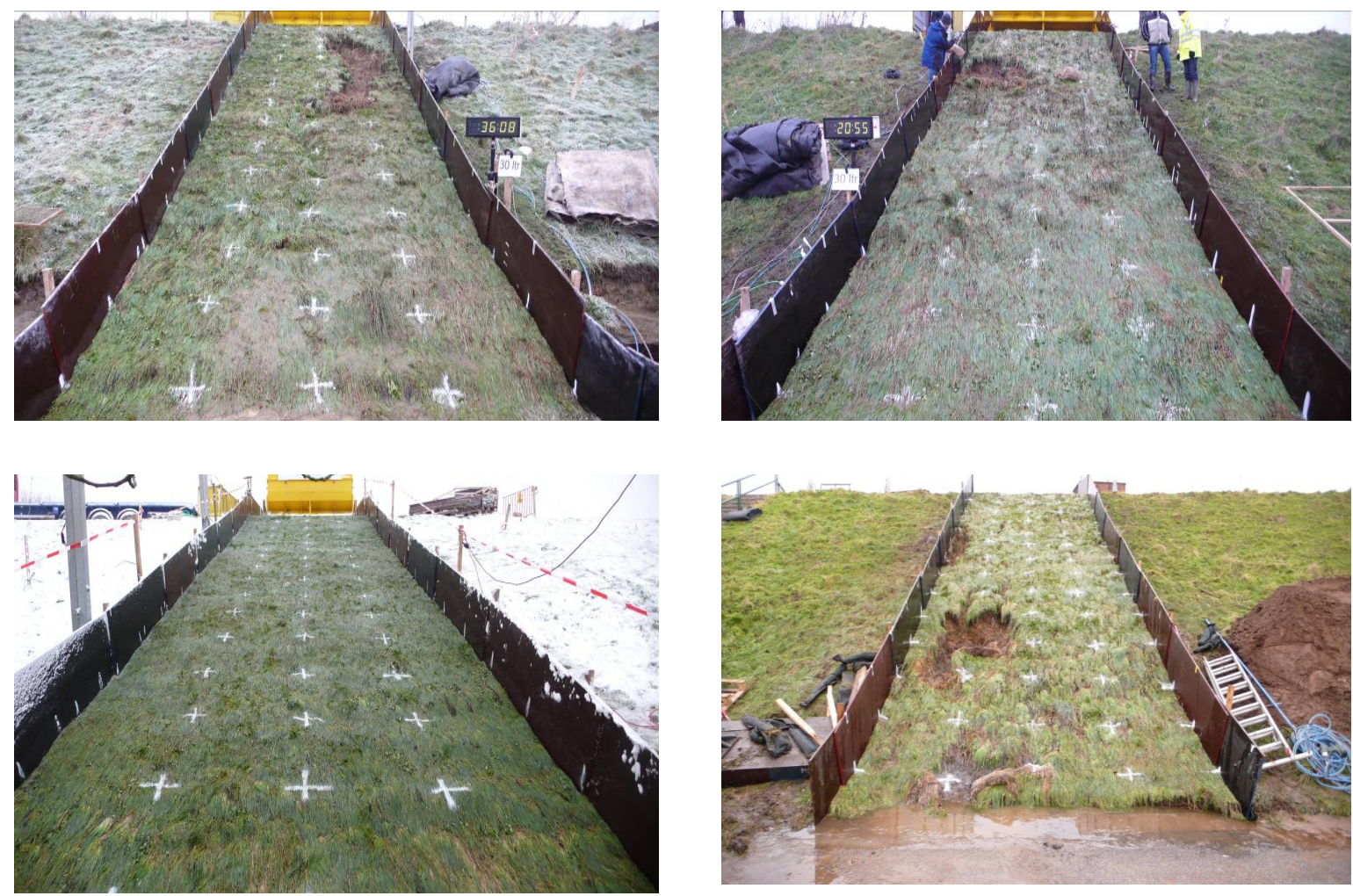

Figure 5. Overview of the test locations after simulating wave overtopping. 


\section{Estimation of Overtopping Flow Parameters}

Each volume that overtops a dike will have a certain flow velocity and depth varying with time. High overtopping velocities and flow depths occur at the front of the overtopping tongue (Fig. 2). The peaks are often referred to as the overtopping velocity $\mathrm{u}$ and layer thickness $\mathrm{h}$. The overtopping rate $\mathrm{q}(\mathrm{t})$ per unit length of the dike is calculated as the product of $\mathrm{h}(\mathrm{t})$ and $\mathrm{u}(\mathrm{t})$. The average overtopping rate $\mathrm{q}$ is generally much lower than the (maximum) instantaneous overtopping rates. Therefore, in order to predict erosion and (shallow) slip failure following (the cumulative load of) consecutive overtopping events, overtopping flow velocities and layer thicknesses of individual overtopping waves are required in addition to average overtopping rates [12]. Fig. 6 presents a wave overtopping definition sketch [13].

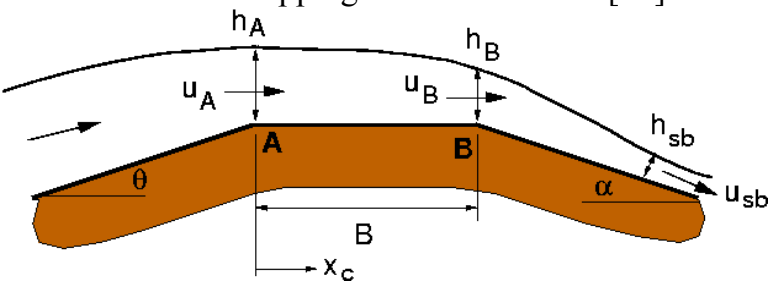

Figure 6. Wave overtopping definition sketch.

\subsection{Wave Front Flow Parameters}

According to Van der Meer [9] the maximum flow depth at the (downstream end of) crest $h_{B}$, is function of the individual overtopping volume $\mathrm{V}$ and given by:

$$
h_{B}=0,133 V^{0,5}\left(h_{\mathrm{B}} \text { in } \mathrm{m} ; \mathrm{V} \text { in } \mathrm{m}^{3} / \mathrm{m}\right)
$$

It should be noted that this relation is mainly fitted on the larger overtopping volumes ranging from 1000 to $5500 \mathrm{l} / \mathrm{m}$ simulated with the overtopping simulator. The following relation for the wave front (depth-averaged) flow velocity $\left(u_{B}\right)$ was derived based on all measurements:

$$
u_{B}=5,0 V^{0,34}\left(\mathrm{u}_{\mathrm{B}} \text { in } \mathrm{m} / \mathrm{s} ; \mathrm{V} \text { in } \mathrm{m}^{3} / \mathrm{m}\right)
$$

Based on laboratory experiments in The Netherlands and in Germany formulae for the wave front depth-averaged flow velocity down the landward-side slope $\mathrm{u}_{\mathrm{sb}}$ and layer thickness $h_{s b}$ were derived [14]. For long distances down the slope, the following equation for the so-called terminal velocity is obtained, also known as the flow formula for open channel flow:

$$
\begin{gathered}
u_{\mathrm{sb} \rightarrow \infty}=\sqrt{\frac{2 h_{s b \rightarrow \infty g \sin \alpha}}{f_{F}}}=\sqrt{C h I}=\frac{R^{2 / 3} s^{1 / 2}}{n} \\
h_{s b}=\frac{h_{B} u_{B}}{u_{s b}}
\end{gathered}
$$

with $\mathrm{g}$, the gravitational acceleration, $\sin \alpha \approx \mathrm{S}$, the angle of the slope (-), C and n, resp. roughness coefficient of Chezy $\left(\mathrm{m}^{1 / 2} \mathrm{~s}^{-1}\right)$ and Manning $\left(\mathrm{m}^{-1 / 3} \mathrm{~s}\right)$ and $\mathrm{R}$, the hydraulic radius $(\mathrm{m})$ (often approximated by $\mathrm{h}$ ).

Dean [4] shows that the terminal velocity is nearly reached within approximate distances of typical land side levee dimensions and that the smaller overtopping discharges (or wave volumes), the earlier the terminal velocity will be reached. In addition, terminal velocities down the land side of the dike will be most likely supercritical. Therefore, when evaluating erosion phenomena, it is suggested to use (the maximum of) both velocities $\left(\mathrm{u}_{\mathrm{B}}\right.$ and $\left.\mathrm{u}_{\mathrm{sb}} \rightarrow \infty\right)$.

\subsection{Characteristic Wave Flow Velocity}

The application of velocity versus duration curves derived for steady overflow (e.g. [5]) to wave overtopping assumes an "erosional equivalence" between both types of loading [15]. Therefore, a characteristic flow velocity should be used that would yield the same erosion as the actual record of the wave flow velocity over the same duration.

According to VTV [16], the characteristic flow velocity at the landward-side of the crest equals:

$$
\mathrm{u}_{\mathrm{char}}=\frac{1}{2} \mathrm{u}_{\mathrm{B}}
$$

Van den Bos [17] states that the characteristic flow velocity at the landward-side of the crest is given by:

$$
\mathrm{u}_{\mathrm{char}}=\frac{1}{\sqrt{2}} \mathrm{u}_{\mathrm{B}}
$$

Dean [4] uses the peak velocity as the characteristic wave velocity.

Van den Bos [17] sets the overtopping time $\mathrm{T}_{\text {ovt }}$ (at the crest) of an individual wave equal to the wave front velocity. Based on wave overtopping simulator tests, Van der Meer [9] proposes to describe the overtopping time at the crest by:

$$
T_{\text {ovt }}=4,4 V^{0,3}\left(\mathrm{~T}_{\text {ovt }} \text { in } \mathrm{s} ; \mathrm{V} \text { in } \mathrm{m}^{3} / \mathrm{m}\right)
$$

\section{Assessment of the Stability of the Grass-covered Land Side Slope}

\subsection{Time of Vegetal Cover Failure}

When the failure mode is erosion through the vegetal cover and under the assumption that (effective) shear stress is much larger than the critical one, the following relation describing time of vegetal cover failure was calibrated from field data [6]:

$$
\int_{0}^{t_{f}} \tau_{e} d t=9 I_{p}+50
$$

with $t_{f}$, time of failure $(s), I_{p}$, plasticity index, $\tau_{e}$, effective shear stress $\left(\mathrm{N} / \mathrm{m}^{2}\right)$ and $\mathrm{dt}\left(=\mathrm{T}_{\mathrm{ovt}}\right)$, overtopping duration $(\mathrm{s})$.

Neglecting the effect of the sward being laid down during flow in reducing shear stresses at the soil-water interface as well as form drag due to localized surface irregularities, the (effective) (bed) shear stress is obtained is calculated by:

$$
\tau_{e}=\rho_{w} g h S
$$

with $\rho_{\mathrm{w}}$, the density of water $\left(\mathrm{kg} / \mathrm{m}^{3}\right)$.

Table 2 shows the estimated and observed time of grass cover failure. A possible overestimation of the effective shear stresses attributes to the rather conservative outcomes. 
Table 2 Estimated and observed time of grass cover failure.

\begin{tabular}{|c|c|c|c|c|c|c|}
\hline \multicolumn{2}{|c|}{ Time of failure (u:mm)* } & $\begin{array}{c}\text { Manning's } n \\
\left(\mathrm{~m}^{-1 / 3} \mathrm{~s}\right)\end{array}$ & $\mathrm{u}_{\text {char }}$ & $\begin{array}{l}\text { Section } 1 \& 2 \\
\left(\mathrm{H}_{\mathrm{s}}=0.75-1 \mathrm{~m}\right)\end{array}$ & $\begin{array}{c}\text { Section 3 } \\
\left(\mathrm{H}_{\mathrm{s}}=0.75-1 \mathrm{~m}\right)\end{array}$ & $\begin{array}{l}\text { Section } 4 \\
\left(\mathrm{H}_{\mathrm{s}}=3 \mathrm{~m}\right)\end{array}$ \\
\hline \multicolumn{2}{|r|}{ Observed } & & & $2: 40-2: 55$ & $>6: 25$ & $7: 00$ \\
\hline \multicolumn{2}{|r|}{ Temple (1992) } & 0,020 & $\mathrm{u}_{\mathrm{sb} \rightarrow \infty}$ & $0: 55-1: 15$ & $1: 15-2: 50$ & $1: 55-2: 55$ \\
\hline \multicolumn{2}{|r|}{$I_{p}=5-10$ or $10-30$} & & $\frac{1}{\sqrt{2}} \mathrm{u}_{\mathrm{sb} \rightarrow \infty}$ & $1: 30-2: 05$ & $2: 40-4: 10$ & $3: 55-4: 50$ \\
\hline & & & $\frac{1}{2} \mathrm{u}_{\mathrm{sb} \rightarrow \infty}$ & $1: 50-2: 35$ & $3: 50$ - >6:25 & $5: 55->7: 00$ \\
\hline \multirow{9}{*}{ 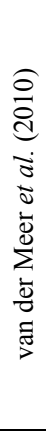 } & $\mathrm{u}_{\mathrm{c}}=1 \mathrm{~m} / \mathrm{s}$ & - & $\mathrm{u}_{\mathrm{B}}$ & $2: 30$ & $(2: 30-)>3: 10$ & $5: 50$ \\
\hline & & 0,020 & $\mathrm{u}_{\mathrm{sb} \rightarrow \infty}$ & $1: 20$ & $(1: 40-)>2: 30$ & 4:00 \\
\hline & & 0,025 & $\mathrm{u}_{\mathrm{sb} \rightarrow \infty}$ & $1: 45$ & $(2: 10-)>2: 55$ & $4: 40$ \\
\hline & $\mathrm{u}_{\mathrm{c}}=2 \mathrm{~m} / \mathrm{s}$ & & $\mathrm{u}_{\mathrm{B}}$ & $3: 30$ & $(3: 30-)>4: 30$ & 7:00 \\
\hline & & 0,020 & $\mathrm{u}_{\mathrm{sb} \rightarrow \infty}$ & 2:05 & $(2: 35-)>3: 10$ & $4: 15$ \\
\hline & & 0,025 & $\mathrm{u}_{\mathrm{sb} \rightarrow \infty}$ & $2: 40$ & $(3: 05-)>4: 00$ & $5: 15$ \\
\hline & $\mathrm{u}_{\mathrm{c}}=4 \mathrm{~m} / \mathrm{s}$ & - & $\mathrm{u}_{\mathrm{B}}$ & $>4: 25$ & $>6: 25$ & $>>7: 00$ \\
\hline & & 0,020 & $\mathrm{u}_{\mathrm{sb} \rightarrow \infty}$ & $>4: 25$ & $(5: 15-)>\mathbf{6 : 2 5}$ & 6:00 \\
\hline & & 0,025 & $\mathrm{u}_{\mathrm{sb} \rightarrow \infty}$ & $>4: 25$ & $>6: 25$ & $>7: 00$ \\
\hline \multirow{27}{*}{ 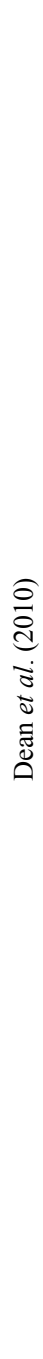 } & Good cover & - & $\mathrm{u}_{\mathrm{B}}$ & $>4: 25$ & $>6: 25$ & $>>7: 00$ \\
\hline & & - & $\frac{1}{\sqrt{2}} \mathrm{u}_{\mathrm{B}}$ & $>4: 25$ & $>6: 25$ & $>>7: 00$ \\
\hline & & - & $\frac{1}{2} \mathrm{u}_{\mathrm{B}}$ & $>4: 25$ & $>6: 25$ & $>>7: 00$ \\
\hline & & 0,020 & $\mathrm{u}_{\mathrm{sb} \rightarrow \infty}$ & $>4: 25$ & $5: 45$ & $>7: 00$ \\
\hline & & 0,020 & $\frac{1}{\sqrt{2}} \mathrm{u}_{\mathrm{sb} \rightarrow \infty}$ & $>4: 25$ & $>6: 25$ & $>>7: 00$ \\
\hline & & 0,020 & $\frac{1}{2} \mathrm{u}_{\mathrm{sb} \rightarrow \infty}$ & $>4: 25$ & $>6: 25$ & $>>7: 00$ \\
\hline & & 0,025 & $\mathrm{u}_{\mathrm{sb} \rightarrow \infty}$ & $>4: 25$ & $>6: 25$ & $>>7: 00$ \\
\hline & & 0,025 & $\frac{1}{\sqrt{2}} \mathrm{u}_{\mathrm{sb} \rightarrow \infty}$ & $>4: 25$ & $>6: 25$ & $>>7: 00$ \\
\hline & & 0,025 & $\frac{1}{2} \mathrm{u}_{\mathrm{sb} \rightarrow \infty}$ & $>4: 25$ & $>6: 25$ & $>>7: 00$ \\
\hline & Average cover & - & $\mathrm{u}_{\mathrm{B}}$ & $>4: 25$ & $5: 50$ & $>>7: 00$ \\
\hline & & - & $\frac{1}{\sqrt{2}} \mathrm{u}_{\mathrm{B}}$ & $>4: 25$ & $>6: 25$ & $>>7: 00$ \\
\hline & & - & $\frac{1}{2} \mathrm{u}_{\mathrm{B}}$ & $>4: 25$ & $>6: 25$ & $>>7: 00$ \\
\hline & & 0,020 & $\mathrm{u}_{\mathrm{sb} \rightarrow \infty}$ & 3:05 & $4: 10$ & 5:05 \\
\hline & & 0,020 & $\frac{1}{\sqrt{2}} \mathrm{u}_{\mathrm{sb} \rightarrow \infty}$ & $>4: 25$ & $>6: 25$ & $\gg 7: 00$ \\
\hline & & 0,020 & $\frac{1}{2} \mathrm{u}_{\mathrm{sb} \rightarrow \infty}$ & $>4: 25$ & $>6: 25$ & $>>7: 00$ \\
\hline & & 0,025 & $\mathrm{u}_{\mathrm{sb} \rightarrow \infty}$ & $>4: 25$ & $5: 10$ & $>7: 00$ \\
\hline & & 0,025 & $\frac{1}{\sqrt{2}} \mathrm{u}_{\mathrm{sb} \rightarrow \infty}$ & $>4: 25$ & $>6: 25$ & $>>7: 00$ \\
\hline & & 0,025 & $\frac{1}{2} \mathrm{u}_{\mathrm{sb} \rightarrow \infty}$ & $>4: 25$ & $>6: 25$ & $>>7: 00$ \\
\hline & Poor cover & - & $\mathrm{u}_{\mathrm{B}}$ & 4:05 & $4: 10$ & $6: 35$ \\
\hline & & - & $\frac{1}{\sqrt{2}} \mathrm{u}_{\mathrm{B}}$ & $>4: 25$ & $>6: 25$ & $>>7: 00$ \\
\hline & & - & $\frac{1}{2} \mathrm{u}_{\mathrm{B}}$ & $>4: 25$ & $>>6: 25$ & $>>7: 00$ \\
\hline & & 0,020 & $\mathrm{u}_{\mathrm{sb} \rightarrow \infty}$ & $2: 35$ & $2: 50$ & $2: 25$ \\
\hline & & 0,020 & $\frac{1}{\sqrt{2}} \mathrm{u}_{\mathrm{sb} \rightarrow \infty}$ & $3: 45$ & $4: 35$ & $6: 00$ \\
\hline & & 0,020 & $\frac{1}{2} \mathrm{u}_{\mathrm{sb} \rightarrow \infty}$ & $>4: 25$ & $>6: 25$ & $>>7: 00$ \\
\hline & & 0,025 & $\mathrm{u}_{\mathrm{sb} \rightarrow \infty}$ & 3:00 & $3: 35$ & $4: 25$ \\
\hline & & 0,025 & $\frac{1}{\sqrt{2}} \mathrm{u}_{\mathrm{sb} \rightarrow \infty}$ & $>4: 25$ & $5: 40$ & $>7: 00$ \\
\hline & & 0,025 & $\frac{1}{2} \mathrm{u}_{\mathrm{sb} \rightarrow \infty}$ & $>4: 25$ & $>>6: 25$ & $>>7: 00$ \\
\hline
\end{tabular}




\subsection{Cumulative Overload}

Van der Meer [9] noticed from observations that the impact of the wave front on the grass cover (even within only tenths of seconds) causes initiation or further development of damage. Hence, the impact, i.e. the maximum flow velocity, rather than the duration is an important parameter to evaluate grass cover erosion. An erosional index called "cumulative overload" is proposed in which the overtopping duration is omitted:

$$
\sum\left(u^{2}-u_{c}^{2}\right) \quad\left(\mathrm{m}^{2} / \mathrm{s}^{2}\right)
$$

with $u_{c}$, the critical velocity, actually a strength parameter of the grass cover and $\mathrm{u}$, the front velocity of the overtopping wave.

The following guidance is provided:

- Start of damage

- Various damaged locations

- Failure due to animal activity,

surface irregularities, ...

- Non-failure for well-maintained slopes

$500 \mathrm{~m}^{2} / \mathrm{s}^{2}$ $1000 \mathrm{~m}^{2} / \mathrm{s}^{2}$

Van der Meer [9] argues that $u_{c}$ will probably be in the range of 4-7 m/s for well-maintained grass covers without open spots. Start of damage and various damaged locations seems hard to predict accurately. Failure, however, is estimated fairly well.

Applying the cumulative overload method to all sections using the front velocities at the crest gives good results (Notice the relatively small critical velocities used!). However, when using the (terminal) front velocities at the landward slope, time of failure and hence the strength of the grass cover is often underestimated (table 2). It can be argued that the cumulative overload method does not account for (superficial) instability and is therefore (possibly) not applicable to a poor grass cover. On the other hand, as riverine overtopping conditions tend to approach continuous overflow, maybe smaller critical velocities (as often reported for overflow conditions) should be applied.

\subsection{Erosion Equivalence}

Dean [4] fitted the hydraulic indicators velocity, shear stress and work to the grass-cover curves mentioned in [5]. The Excess Work $E_{\mathrm{W}}$ gave the smallest standard error for all grass qualities given the following relation and the values in Table 3:

$$
\begin{array}{r}
E_{W}=K_{W}\left(W-W_{c}\right) t=K_{W}^{\prime}\left(u^{3}-u_{c, W}^{3}\right) t \\
\text { for } \mathrm{u}>\mathrm{u}_{\mathrm{c}, \mathrm{w}}
\end{array}
$$

By using the wave front velocity at the landward slope, Dean [4] is somewhat conservative, yielding in an underestimation of the time of failure. Assuming a characteristic velocity as proposed by Van den Bos [17] seems to yield fairly good results (Table 2).
Table 3. Results for the fit of eq. 11 to the grass-cover curves according to [3].

\begin{tabular}{|c|c|c|}
\hline Plain grass & $\begin{array}{c}\text { Erosion limit } \mathrm{E}_{\mathrm{W}} / \mathrm{K}^{\prime}{ }_{\mathrm{w}} \\
\left(\mathrm{m}^{3} / \mathrm{s}^{2}\right)\end{array}$ & $\begin{array}{c}\text { Treshold velocity } \mathrm{u}_{\mathrm{c},} \\
\mathrm{w}(\mathrm{m} / \mathrm{s})\end{array}$ \\
\hline Good cover & $0,49210^{6}$ & 1,80 \\
\hline Average cover & $0,22910^{6}$ & 1,30 \\
\hline Poor cover & $0,10310^{6}$ & 0,76 \\
\hline
\end{tabular}

\subsection{Turf Sliding}

Young [7] describes superficial sliding of the top layer as one of the possible failure mechanisms for slopes subject to overtopping. For superficial sliding to occur, the soil is assumed to be fully saturated and parallel seepage is assumed to exist.

It is known that, due to soil structure of the top layer, the permeability of the top layer is much larger. Values of 10-5 to $10-4$ can be found in literature. This would confirm the hypothesis that the soil is fully saturated.

According to Marsland [18], the factor of safety (FoS) for slip of a fissured, permeable clay layer, can be expressed as the ratio of the effective soil shear strength $\left(c^{\prime}+\gamma^{\prime} \cdot d\right.$. $\cos \alpha \cdot \tan \varphi)$ to the saturated weight of the soil on the slope $\left(\gamma_{\mathrm{s}} \cdot \mathrm{d} \cdot \sin \alpha\right)$ :

$$
F o S=\left(c^{\prime}+\gamma^{\prime} d \cos \alpha \tan \varphi\right) /\left(\gamma_{s} d \sin \alpha\right)
$$

with c' and $\phi$ ' the effective soil strength parameters, $d$ the depth of the failure surface, $\alpha$ the slope angle, $\gamma^{\prime}$ the submerged soil weight and $\gamma_{\mathrm{s}}$ the saturated soil weight.

Young [7] notes that effective cohesion at superficial depths should be ignored. On the other hand, one can account for an increase in shear strength due to the presence of roots (root-reinforcement) by applying a so called root cohesion $\mathrm{c}_{\mathrm{r}}$. This results in an equation similar to equation (12), but this time with a root cohesion cr instead of an effective cohesion c':

$$
\text { FoS }=\left(c_{r}+\gamma^{\prime} d \cos \alpha \tan \varphi\right) /\left(\gamma_{s} d \sin \alpha\right)
$$

According to literature (a.o. [7], [19] and [20]), root cohesion can amount up to19 $\mathrm{kPa}$. Most sources however mention root cohesion up till $4 \mathrm{kPa}$.

Young [7] describes two other effects that should be taken into account when calculating the possibility of superficial sliding. First of all, the additional shear stress which is exerted on the surface due to the flow over the surface and secondly the uplift effect on the top layer due to the fact that the flow due to overtopping events is not continuous. According to the calculations made by Young [7], the latter has only little influence on the stability of the top layer. The effect of the additional shear stress due to the flow on the slope can be expressed as an additional load:

$$
F o S=\frac{c_{r}+\gamma^{\prime} d \cos \alpha \tan \varphi}{\gamma_{s} d \sin \alpha+\frac{\gamma_{W} u_{B \text { or } s b}^{2}}{C^{2}}}
$$

with $\gamma_{w}$ the unit weight of water, $u_{B}$ or $s_{b}$ the (maximum) overtopping velocity and $\mathrm{C}$ the coefficient of Chezy.

The influence of the variation of the root cohesion, the depth beneath the surface, the flow velocity $\mathrm{u}_{\mathrm{B}}$ or $\mathrm{s}_{\mathrm{b}}$ and the 
coefficient of chezy $\mathrm{C}$ on the factor of safety is calculated. Table 4 gives the values of the parameters which were used for the two locations. The parameters are assessed based on the information of the local geotechnical tests which were performed and the information on the different parameters in Young [7].

Table 4. Values of the parameters, applied in equations (12) and (14) for both locations.

\begin{tabular}{|c|c|c|c|c|c|}
\hline Location & Slope & $\phi$ & $\gamma^{\prime}$ & $\gamma_{\mathrm{s}}$ & $\gamma_{\mathrm{w}}$ \\
\hline$[-]$ & {$[-]$} & {$\left[{ }^{\circ}\right]$} & {$\left[\mathrm{kN} / \mathrm{m}^{3}\right]$} & {$\left[\mathrm{kN} / \mathrm{m}^{3}\right]$} & {$\left[\mathrm{kN} / \mathrm{m}^{3}\right]$} \\
\hline Test 2 & $1: 2.5$ & 22 & 8 & 17 & 10 \\
\hline Test 3 & $1: 3.5$ & 22 & 8 & 17 & 10 \\
\hline
\end{tabular}

The influence of the root cohesion in equation (11) is shown in Figure 7 for the two different slopes which were tested (1:2.5 and 1:3.5 slope). It can be noticed that, for $\mathrm{c}_{\mathrm{r}}=0$ $\mathrm{kPa}$, both slopes have a FoS $<1$. For the slope of 1:3.5, the $\mathrm{FoS}>1$, if $\mathrm{c}_{\mathrm{r}}>1 \mathrm{kPa}$. For the slope of $1: 2.5$, the FoS $>1$, if $\mathrm{c}_{\mathrm{r}}>$ $3 \mathrm{kPa}$.

To account for the forces caused by the flow due to overtopping, Equation (14) is applied in Figure 8 and Figure 9. In Figure 8 , the influence of the overtopping velocity $\mathrm{u}_{\mathrm{B}}$ or $\mathrm{s}_{\mathrm{b}}$ is shown. In Figure 9, the influence of the Chezy coefficient is shown. Figure 8 shows that the influence of the flow velocity is large, especially for shallow depths. Figure 9 shows that the influence of the Chezy coefficient (and thus the roughness height) is limited. The Chezy coefficient was varied between 25 and $35 \mathrm{~m}^{0.5} / \mathrm{s}$, which are typical values for a grass layer [7]. An increase in roughness height however, corresponds with a decrease of the Chezy coefficient and a decrease of FoS value.

The calculations show that it is possible for superficial sliding to occur during the performed tests. A necessary condition is the saturation of the slopes during the tests and parallel seepage. In this regard, infiltration tests were performed on the slopes at the two locations of the tests, close to the actual locations of the tests. An infiltration rate of $1 \cdot 10-4$ to $3 \cdot 10-4 \mathrm{~m} / \mathrm{s}$ was measured halfway down the slope, confirming a high permeability of the top layer. The infiltration tests were performed with a single cylinder with a diameter of approximately $40 \mathrm{~cm}$.

In addition, the saturation of the soil was measured with piezometers and thetaprobes (based on the measurement of the dielectrical constant of the soil, which depends on the moisture content) during two tests (test 2 and test 3 ). The results of the measurements are shown in Figure 10 and 11. Due to the cold weather, not all measurements succeeded, but the results clearly show that at both locations, saturation of the soil is obtained very quickly at depths up to $90 \mathrm{~cm}$ below soil level. A difference between the two test locations is the drainage between two subsequent tests. During test 2 (1:2.5 slope), the slope remained saturated even in between tests. A small increase in saturation was noticed throughout the whole test (Fig. 10). It was also seen that the slope became oversaturated. During test 3 (1:3.5 slope), the slope was able to drain in between tests (Fig. 11). This might be an additional reason why superficial sliding was more likely to occur during test 2 (and tests 1 and 4), in comparison with test 3 .

Although sliding is not dependent on the effect of erosion, both can occur simultaneously [7], making it more difficult to determine the exact failure mechanism during the tests.
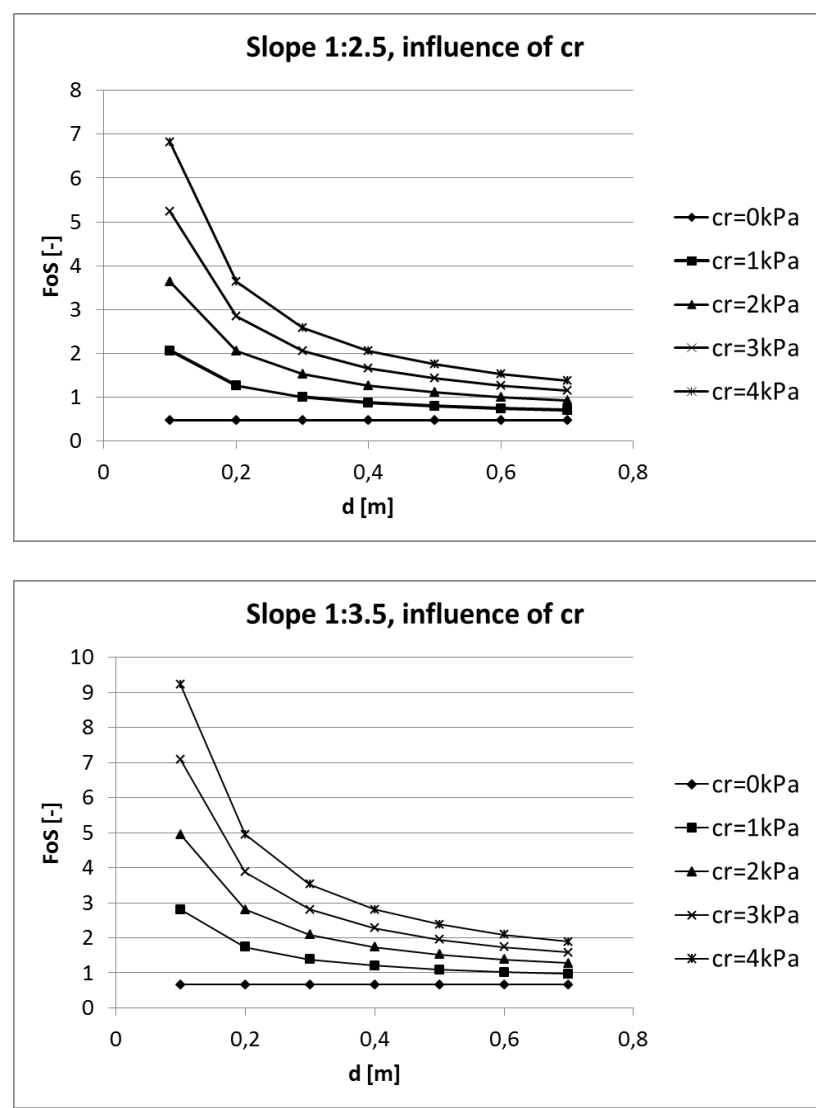

Figure 7. Influence of root cohesion $\mathrm{c}_{\mathrm{r}}$ on FoS for superficial sliding (eq. 12) 

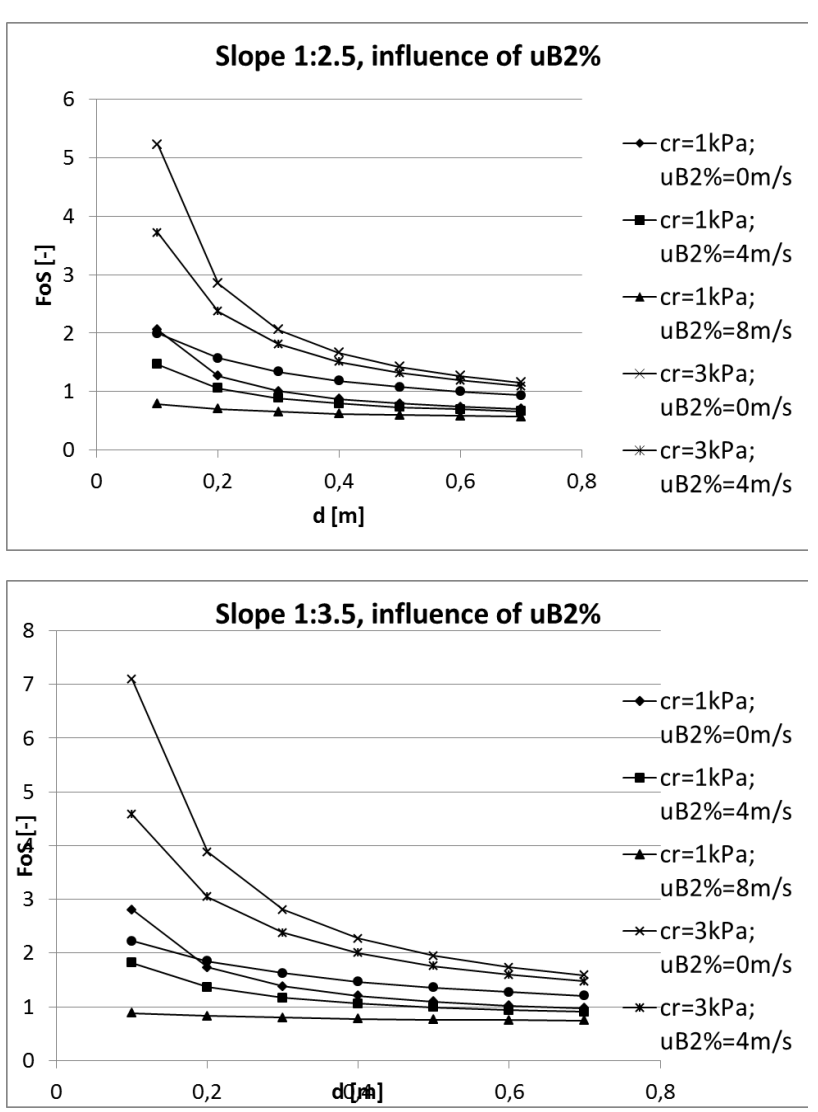

Figure 8. Influence of flow velocity $\mathrm{u}_{\mathrm{B}}$ or sb on FoS for superficial sliding (eq. 13), $\mathrm{C}=25 \mathrm{~m}^{0.5} / \mathrm{s}$
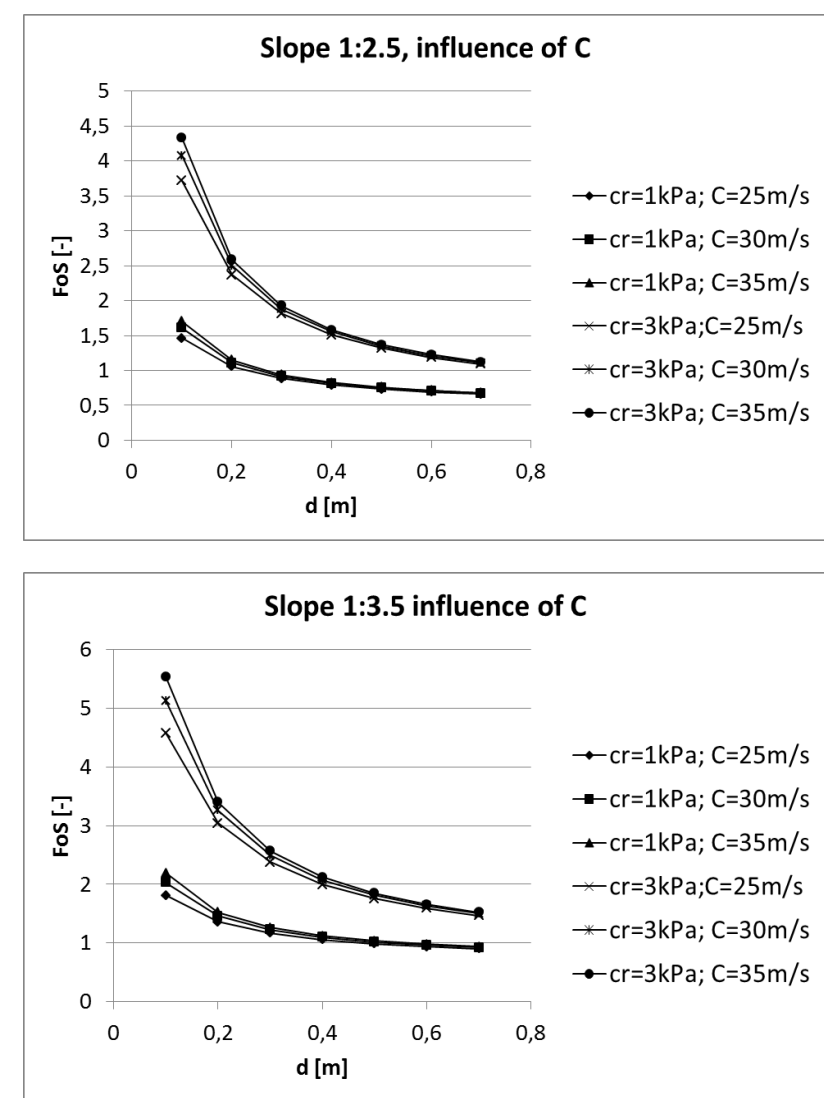

Figure 9. Influence of coefficient of Chezy $\mathrm{C}$ on FoS for superficial sliding (eq. 13), $\mathrm{u}_{\mathrm{B} \text { or } \mathrm{sb}}=4 \mathrm{~m} / \mathrm{s}$

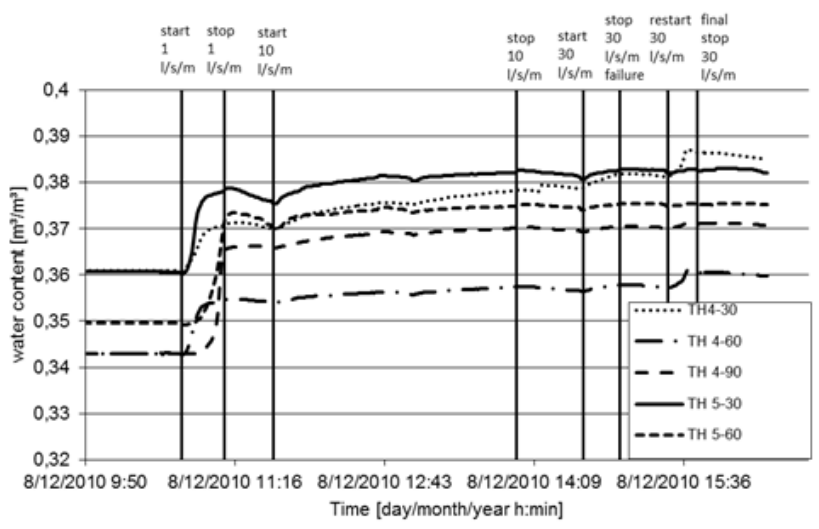

Figure 10. TEST 2: saturation of the soil, measured at different depths (30, 60 and $90 \mathrm{~cm}$ below soil surface) and different locations (top of the slope, centrally and at the bottom of the slope).

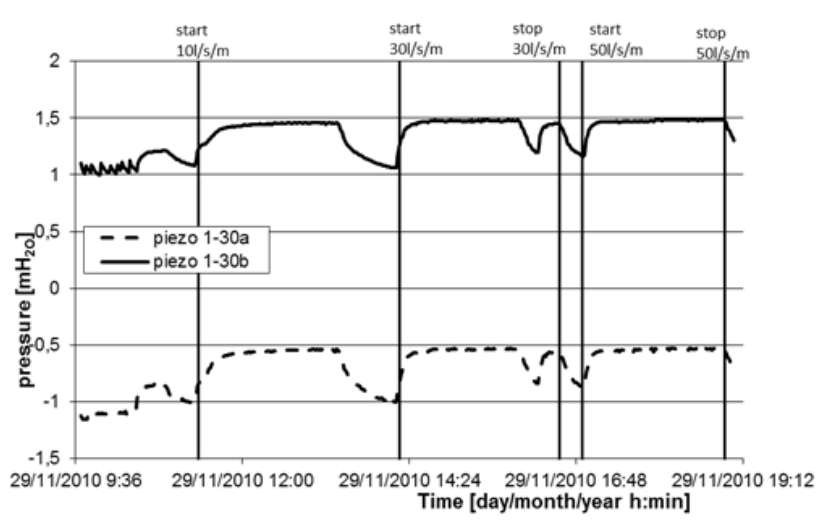

Figure 11. TEST 3: saturation of the soil, measured at a depth of $30 \mathrm{~cm}$ below soil surface at the top of the slope.

\section{Discussion \& Conclusions}

Different methodologies for assessing the (in) stability of the grass cover of a dike are applied and compared to the results of in situ wave overtopping test in Tielrode (Belgium).

It should be noted that the flow parameters (hydraulic indicators) along the landward slope are sensitive to the chosen roughness value. Of course when assessing the cumulative effect above a certain threshold, this (somewhat arbitrary chosen) threshold is a critical strength parameter in all possible meanings. As a result, a wide spread in the calculated results is found.

The cumulative overload method stresses the importance of the impact of the wave front. However, due to the almost 1-to-1 relation between front velocity and the overtopping duration, it is implicitly accounted for. As a consequence, not shear stress but rather the (front) velocity is considered as a measure of erosion.

The difference in critical velocities suggested are a consequence of the different approaches in describing the load part, either by assuming an erosional equivalence between continuous and intermittent flows, either by focusing on the impact of the wave front. Based on the above 
results (especially for riverine wave conditions which in fact tends towards continuous overflow), the following relation between both critical velocities is suggested:

$$
u_{c, \text { erosion equivalence }}=\frac{1}{2} \text { à } \frac{1}{\sqrt{2}} u_{c, \text { cumulative overload }}
$$

More in situ research should be executed in order to better understand the change in wave (front) velocity along the landward slope.

It was found that at all locations, the saturation of the soil up to a depth of $1 \mathrm{~m}$, took place very quickly. Calculations show that at all locations, superficial sliding is possible, depending on the boundary conditions. Beside the difference in slope, it was found that, at the locations where damage occurred, the soil was unable to drain in between tests, possibly increasing the risk of superficial sliding of the top layer. As different mechanisms may interact, it is more difficult to determine the exact failure mechanism during the tests.

\section{Recommendations}

The first method uses the plasticity index of the topsoil (as a measure for the cohesion of the cover layer, neglecting possible contribution due to the presence of roots). The other methods try to account for the (root-)reinforcement of the topsoil via the critical or threshold velocity of the vegetation or the added root cohesion. The determination of these threshold values is at-the-time still questionable.

The effect of the sward being laid down during flow, overlapping each other and hence reducing shear stresses at the soil-water interface and localized surface irregularities should be accounted for in assessing the load part, especially when dealing with a uniform grass cover as was the case at location 3 .

Finally, in order to allow average wave overtopping discharges up to $10 \mathrm{l} / \mathrm{s}$ per $\mathrm{m}$ it is recommend to pay attention to localized concave surface (following mismanagement), avoid (more) woody vegetation which can be an indication for the presence of small cliffs as well as a damaged grass cover and aim at a uniform vegetation coverage of $80 \%$ and more.

\section{Acknowledgments}

Special thanks goes to the Flemish water authority Waterwegen \& Zeekanaal, Division Zeeschelde, The Dutch Ministry of Public Works (Rijkswaterstaat) as well as the consulting company Infram.

\section{REFERENCES}

[1] Waterwegen en Zeekanaal N.V. (2005). Geactualiseerd
Sigmaplan voor veiligheid en natuurlijkheid in het bekken van de Zeeschelde - Synthesenota (in Dutch)

[2] Valk, A. (2009). Wave overtopping - Impact of water jets on grassed inner slope transitions. MSc-Thesis, TUDelft, Delft.

[3] Knapen, A; Poesen, J.; Govers, G.; Gyssels, G. \& Nachtergaele, J. (2006). Resistance of soils to concentrated flow erosion: A review. ScienceDirect.

[4] Dean, R.G.; Rosati, J.D.; Walton, T.L.; Edge, B.L. (2010). Erosional equivalences of levees: Steady and intermittent wave overtopping. Ocean Engineering 37 (2010) 104-113.

[5] Hewlett, H.W.M.; Boorman, L.A. \& Bramley, M.E. (1987). Design of reinforced grass waterways. CIRIA Report 116.

[6] Temple, D.M. (1992). Estimating flood damage to deep soil spillways. Applied Engineering in Agriculture 8(2): 237-242.

[7] Young, M.J. (2005). Wave Overtopping and Grass Cover Layer Failure on the Inner Slope of Dikes. MSc thesis, IHE, Delft.

[8] Van der Meer, J.W.; Bernardini, P.; Steendam, G.J.; Akkerman, G.J.; Hoffmans, G.J.C.M. (2007). The wave overtopping simulator in action. Proc. Coastal Structures, Venice, Italy.

[9] Van der Meer, J.W.; B. Hardeman; G.J. Steendam; H. Schttrumpf \& H. Verheij. (2010). Flow depths and velocities at crest and inner slope of a dike, in theory and with theWave Overtopping Simulator. ASCE, Proc. ICCE 2010, Shanghai.

[10] Peeters, P.; De Vos, L.; Vandevoorde, B.; Taverniers, E.; Mostaert, F. (2012). Erosiebestendigheid van de grasmat bij golfoverslag: Golfoverslagproeven Tielrodebroek. Versie 2_0. WL Rapporten, 713_15b. Waterbouwkundig Läboratorium, INBO en afdeling Geotechniek: Antwerpen, België. (in Dutch)

[11] Steendam, G.J.; Peeters, P.; van der Meer, J.W.; Van Doorslaer, K. \& Trouw, K. (2011).. Destructive wave overtopping tests on Flemish dikes. ASCE, Proc. Coastal Structures 2011, Yokohama, Japan.

[12] Schüttrumpf, H. \& Oumeraci, H. (2005). Layer thicknesses and velocities of wave overtopping flow at seadikes. Coastal Engineering 52:473-95.

[13] Hughes, S. (2008). Estimation of Overtopping Flow Velocities on Earthen Levees Due to Irregular Waves. US Army Corps of Engineers - ERDC.

[14] Schüttrumpf, H. \& van Gent, M.R. (2003). Wave overtopping at seadikes. In Proceedings, Coastal Structures, '03, 431-443. Washington, DC: American Society of Civil Engineers.

[15] Hughes, S. (2011). Adaptation of the Levee Erosional Equivalence Method for the Hurricane Storm Damage Risk Reduction System (HSDRRS). US Army Corps of Engineers - ERDC.

[16] Anon. (2007). Voorschrift Toetsen op Veiligheid Primaire Waterkeringen. Iov. Ministerie van Verkeer en Waterstaat Directoraat-Generaal Water, Den Haag. (in Dutch)

[17] Van den Bos, W. (2006). Erosiebestendigheid van grasbekleding tijdens golfoverslag. MSc-thesis, TUDelft, 


\section{Delft. (in Dutch)}

[18] Marsland, A. (1966), The design and construction of earthen floodbanks, Chapter 24, River Engineering and Water Conservation Works (Ed. R.B. Thorn), Butterworths, London.

[19] De Baets, S.; Poesen, J.; Reubens, B.; Wemans, K.; De
Baerdemaeker, J.; Muys, B. (2008). Root tensile strength and root distribution of typical Mediterranean plant species and their contribution to soil shear strength. Plant Soil, Springer.

[20] Hoffmans, G.; Akkerman, G.J.; Verheij, H.; Van Hoven, A. \& van der Meer, J. (2008). The erodibility of grassed inner dike slopes against wave overtopping. 